\title{
The Dream Vision: The Other as the Self
}

\author{
Natanela Elias
}

Independent Scholar, Israel

Copyright $\bigcirc 2018$ by authors, all rights reserved. Authors agree that this article remains permanently open access under the terms of the Creative Commons Attribution License 4.0 International License

\begin{abstract}
The Middle Ages were hardly known for their openness or willingness to accept the other, however, research indicates that things were not quite as they seemed. In this particular presentation, I would like to introduce the possibility of resolving conflict (social, political, religious) via literature, and more specifically, through the use of the popular medieval genre of the dream vision.
\end{abstract}

Keywords Middle Ages, Self, Other, English literature, John Gower

\section{Introduction}

In our day and age, as we attempt to aspire to tolerance and acceptance, we must still acknowledge the existence of animosity, intolerance and discrimination. I believe that by examining some of its origins, we might reach some kind of realization.

The Middle Ages (c. 1066-1500) were hardly known for their openness or willingness to accept the other, however, research indicates that things were not quite as they seemed. In this particular work, I would like to introduce the possibility of resolving conflict (social, political, religious) via literature, and more specifically, through the use of the popular medieval genre of the dream vision as depicted in John Gower's Confessio Amantis. This genre encapsulates a deconstructive structure which centralizes the margins (namely, that which can usually be categorized as "the Other" in society) in a manner that eventually leads to a form of self-revelation. In other words, in this process and through this genre, the self ironically awakens into a 'parallel' existence that with the use of storytelling, remembrance, and self-reflection, ultimately enables a re-encounter with "the other" within.

Just like the poets of old attempted to understand the world around them through their writings, I believe much of the same can be done if appropriately applied in our post-post-modern ( $21^{\text {st }}$ century), somewhat jaded times.

The process of "self-discovery" or of self-reflection is certainly not new to literature. But it takes a unique literary style to induce, for lack of a better description, such a reader response. Dream visions form a literary combination of sleeping dreams and waking visions. In other words, the structure of the dream vision enables the necessary state of repose which ironically may lead to a re-awakening in the search for Truth. Barbara Newman [1] claims that dreams of this kind, "like waking visions, focus less on predicting the future than on achieving self-knowledge, entering vividly into past events, or manifesting eternal truths".

According to William Hodapp [2], and as we will try to delineate in this work, the structure of such visionary texts can be outlined "in four movements: first, the narrator describes an experience that suggested his initial psychological state; second, the narrator recounts a new experience detailing a changed state of consciousness during which he encountered other characters; third, the narrator describes an exchange, in this case as a dialogue between the narrator and these other characters, through which he gained knowledge; and finally, the narrator describes the aftermath of this exchange."

The dream vision may appear as a 'personal' experience, and indeed, it is. However, this personal experience quickly becomes communal as the genre serves as a general concept that can be applied to literally any man.

In the process of the construction of a society, which Pierre Bourdieu[3] calls "state formation" the linguistic market becomes dominated by the official language which then becomes the legitimate language - that which is accepted - the central, the canonical, the mainstream. Or as the case may be the self. In the process, other discourses necessarily become marginalized and thus illegitimate, which then gives rise to a form of "writing between the lines." Bourdieu "portrays everyday linguistic exchanges as situated encounters between agents endowed with socially structured sources and competencies, in such a way that every linguistic interaction, however personal and insignificant it may seem, bears the traces of the social structure that it both expresses and helps to reproduce," which entails that while every utterance is held in tandem with the canonical rhetorics, it also harbors traces of other existent constructs. In other words, literature in general, and the dream vision in particular create a kind of subversive writing which brings the margins (that is, "the other") into acknowledgement, albeit covertly, but this ultimately opens 
up the possibility for self-reflection that would then perhaps lead to self-revelation and change, both inward and outward.

This covert subversive strategy emerges in response to the existing dogmatic, institutional limitations.

Leo Strauss [4] describes this phenomenon in Persecution and the Art of Writing as "writing between the lines"; "That literature [literature of persecution] is addressed not to all readers, but to trustworthy and intelligent readers only. It has all the advantages of private communication without having its greatest disadvantage - that it reaches only the writer's acquaintances." This structure seems to correlate with the specific choice of genre - the dream vision, where the subversive tends to rise in, as Bourdieu[3] puts it, "the fact that [while] literary or artistic production appears as disinterested, as a haven for gratuitous activity that is ostentatiously opposed to the mundane world of commodities and power, [it] does not mean that it is interest-free; on the contrary, it means only that it is able more easily to conceal its interests beneath the veil of aesthetic purity." In other words, the literature appears "disinterested" while actually possessing elements of "interest," an agenda (again, be social, political, and religious). Much has been said with regard to Gower's socio-political claims; however, what I am proposing runs a bit deeper. In this work, I suggest that instead of applying the macro (i.e., social commentary) unto the micro (i.e., the person), the micro should be perceived as the key to reading/understating/interpreting the macro.

Thus, the "heterodox," "the other," though pushed to the margins, finds its way back into the center via a potent residue that makes an appearance in high-medieval literature (c. 1300-1500). The medieval audience, prominently the thoughtful and affluent ones, was able to find many answers (both personal and global) in the complex literary works, which utilized this residue in their style and content, and which I believe can be applied in our society as well.

The dream vision presents tales in a form of meditation that would lead to remembrance, which would then culminate in knowledge and revelation, both on the personal level and on the communal one. In these literary texts, the dream vision becomes the locus of knowledge, the place of Truth in which that which was absent becomes hauntingly present. Or as Hodapp [2] states: "Dream vision is a sub-genre of the visionary narrative through which authors typically explore interior, spiritual experiences by articulating an irrational dream world within the context of a dreamer's rational waking world," and it is in this irrational dream world (disguised as the rational waking world) that the self-encounters "the other."

Newman [1] explains that the dream "veils a truth in ambiguous metaphors and cries out for interpretation."

The self, who is a representative of mainstream society, cannot know such "truths" on the conscious level, which is exactly why such narratives are required, as they bring that knowledge to the foreground. They place a mirror in front of the self, thus positioning the self/the reader (as the case may be) in the place of the other. And it is through this disconcerting juxtaposition that the self becomes aware of himself. Namely, the structure of the dream vision makes it possible to articulate that which could not have been articulated.

\section{The Confessio Amantis}

Confessio Amantis ${ }^{1}$ emphasizes the importance of passivity in an exercise of storytelling of ethical parables set in dream vision tradition. On the surface, the scheme seems fairly simple for it presents numerous tales inspired by different traditions on the backdrop of the seven deadly sins with an emphasis on some mode of love, or more particularly, lust. However, it is far from simple. Most scholars assert that Gower's Confessio is an attempt to reconcile the socio-political turmoil of the time through the telling of classical tales which should serve to regenerate the common good as well as the individual person. In the following discussion, I would like to take these assertions further and claim that the scope of the Confessio is not only socially oriented but a specifically individual endeavor for salvation in a kind of mystical progress of the soul. In this manner, social change may become possible through personal and individual reflection, which may be attained through a reawakening of the self via the regaining of dormant knowledge. The protagonist - Amans, a lover doesn't seem to belong, for he is in exile from his true self which he wishes to regain; a lover without love, if you will, a subject without the self. Love - Venus and her chaplain, Genius - play here the role of Truth. In other words, the purpose of Genius, Love's messenger, is to instruct Amans in his lost art and save him, and vicariously, society.

The path to revelation, however, is not an easy one for Amans since he is difficult to awaken. The means with which Genius attempts his mission is through story-telling. Story-telling and this mode of confession seem to force the individual into a state of self-reflection. Through the personal experience of the knowledge that the tales aim to impart and a self-re-assessment, the penitent is meant to recall his true self and be saved.

The Confessio is divided into eight books: seven books that deal with the seven deadly sins, with special focus on the last sin - lechery, and one seemingly digressive book about good kingship. This entire process is enabled through the guiding hand that comes in the form of a wise woman Venus, the powerful pagan Goddess of Love and Amans' intended patron. But from the very beginning, this notion is inverted since Amans is, simply put, an unsuccessful lover. On this note, Derek Pearsall[5] discusses Gower's narrative form, claiming that "despite the fiction of the lover's confession, [Gower] is not providing instruction in the art of love, but using love as the bait for instruction in the art of

${ }^{1}$ Part of the following interpretation is based on my published work, titled
The Gnostic Paradigm: Forms of Knowing in English Literature of the Late Middle Ages. Palgrave Macmillan, 2015. 
living." While that may be true on the literal level, on the allegorical level it seems Gower is using love as the subject matter of his instruction on remembering. But remembering what exactly? Love, or rather the message of love, represents an eschatological end as it becomes synonymous with Truth and reflection through the art of storytelling which becomes the means to achieving that end. Nevertheless, it cannot be achieved on one's own, especially due to the obvious ineptness of the initiate, and thus, Venus sends her priest, Genius, to guide Amans in his confession in the hopes that he redeems himself.

\section{The Initial Psychological State}

Gower is obviously unhappy with the current situation in his world, or as Russell Peck suggests, Gower perceives the current social division as the result of narcissism and selfishness, or as I shall claim, forgetfulness and ignorance, which the poem, I believe, aims to treat and rectify. As Steele Nowlin [6] puts it, "that project is to repair the discord of human history manifested as late-fourteenth-century England's particular cultural and historical moment, using a memorial process through which narratives of the past are redistributed through a poetics of the 'middel weie' in order to educate readers on how to use knowledge to improve themselves and their society (Pro. 17)." This notion manifests itself in the repeated appearance of Nebuchadnezzar; his prophetic visions should be taken for a symbolic framework that envelops the poem's overall message. These visions are meant to be read as keys to the understanding of the poem in its entirety. And again, not only is his commentary directed at the spiritual state of humanity but his interest lies in the socio-political world as well. Amans, a type of 'Everyman' character, literally and phonetically 'a man,' is set on this spiritual journey into himself to uncover the Truth of his and vicariously, the world's wrongdoings in order to set things right. Nevertheless, the message is neither communal nor universal as the process is strictly personal. But as salvation is achieved on the individual level, it can and should sweep others as well. It seems the poem is putting the blame on forgetfulness claiming it to be the worst $\sin$ of all. Forgetfulness, I believe, serves as the real framework of the poem with all the other 'conventional' sins grouped together under its roof. Thus, the only remedy for such a sin would be its opposite - remembering - the 'eighth virtue to the eighth sin,' so to speak. And that seems to be precisely the exercise the poem partakes in.

The narrator begins by saying that since books of old have remained in relevance and as we are instructed by what has been written in them, it is time to write something new, relevant to his time but based upon those stories of the past.

\section{A New Experience}

The world is in such disarray precisely because each man sees it in such different and diverse ways that everything has become reversed. The poem will utilize this system in order to indicate exactly how adverse contemporaneous understanding, or lack thereof, truly is. Gower will do so by juxtaposing tales of time past with the present. Through his writing he aims to teach, instruct, but at the same time, he is himself in the process of learning.

Gower [7] proves he is very much immersed in the historical events of his time - discussing the troubling aspects of major proceedings like the Great Schism, the Bad Parliament of 1377, the Peasants' Revolt and Lollardy - but the remedy seems to be the same for all - remembrance "for trowthe mot stonde ate laste" (Prol. 369). The state of disorder the poem is attempting to convey comes both on the literal as well as the metaphorical level. Nebuchadnezzar's visions, as mentioned before, serve as index to the reading of the poem.

His first vision of the statue made of gold, silver, bronze, iron and clay sets up the problem of the world, but also of Amans himself. A thing divided cannot withstand and thus division truly becomes the source of evil. If man is divided within himself, fragmented ("Of cold, of hot, of moist, of drye" (Prol. 977)), ripped asunder in between the body, soul and spirit, then he can no longer be 'a man.' Similarly, the very cosmos can no longer function as it should.

This idea manifests in Nebuchadnezzar's second vision where he is punished for forgetting his true self, or rather allowing himself to become divided and unsure by literally becoming a beast, no longer a man. This depicts the state of humanity at large, of society, at least according to the events Gower recounts since "every man wel knowe,/ Division aboven alle / Is thing which makth the world to falle" (Prol.970-2). The only remedy is to look back at history and recall the greatness that was once possessed. Gower imposes this cure on the microcosm as well since it is memory (i.e., a man's own personal history) that might heal the rifts, remind man of his once possessed greatness, and bring redemption.

\section{The Exchange of Knowledge}

Following Amans' request for a break, Book 7 is somewhat of a digression from the confessional structure. This book does not only offer a twist on the confession but also on the scheme of the seven sins. Instead of presenting the seventh sin - Lust - it digresses into a lengthy lesson on good kingship. Since Amans asks to be taught some kind of wisdom, Genius takes a more active role and tells Amans of Aristotle's "fare / Of Alisandre"(7.4-5). The book, I believe, signifies the final stage before enlightenment since the notion of "Kingship" represents a form of individual maturity and self-reflection that is more powerful than the confessional. In this book, the individual and the state become two sides of the same coin where communal gain may be possibly attained via personal redemption and salvation; attaining 'kingship' on one's own kingdom, if you 
will.

\section{The Aftermath}

Amans then returns our, as well as Gower's focus to the issue at hand - his confession brought on by "loves peine" (7.5414). Amans says he is still restless. He wonders if something that "Touchende of love, as we begonne" (7.5423) may have been "overronne / Or oght forgete or left behinde" (7.5424-5). Genius admits there is one more thing they have yet to discuss "for thou schalt be wel avised / Unto thi schrifte as it belongeth" (7.5434-5), at the end of which "the person who will finally be won over ... is Amans himself"[8]. Following the "Tale of Apollonius," Genius concludes,

For as of this which thou art inne,

Be that thou seist it is a sinne,

And sinne mai no pris deserve;

Withoute pris and who schal serve,

I not what profit myhte availe.

Thus folweth it, if thou travaile

Wher thou no profit hast ne pris,

Thou art toward thiself unwis (8.2087-94)

For as of this which you are in,

Be that you say it is a sin,

And sin may no prize deserve;

Without a prize and someone who will deserve it,

I do not know what profit might be worthy.

Thus follow it, if thou work

Where thou no profit have nor prize,

Thou art toward thyself unwise (my translation)

He claims Amans is well aware that he is not yet in the required state of mind, or in other words, he is still lacking and thus deserves no reward. If there is no prize at the end nor someone to deserve it, Genius is unsure where to go from there and tells Amans to seek that prize because if he doesn't he is unwise towards himself. Namely, if he doesn't heed the message and gain hold of this coveted reward, he is being both unwise and lacking in the necessary knowledge of himself. Amans is blind to his true self and requires "good conseil that he be lad" (8.2107) in order to ironically fall into knowledge. I believe the word "falle" plays on the Original, orthodox fall into sin since it reiterates the lesson of Book 8 , but at the same time, indicates that one has to fall into himself in order to find that which has been sought. The soul is thus at the center of man's kingdom and "If he misreule that kingdom, / He lest himself" (8.2114-5), for he who doesn't know himself intimately, has nothing else, and pearls of wisdom are then no more than empty shells. It is "Hierafterward" (8.2144) that we shall see whether Genius' instruction has been effective, "For I can do to thee no more / Bot teche thee the rihte weie" (8.2146-7).

\section{Conclusions}

The moment of truth has come and the poem has finally reached full circle as Amans is again confronted with the choice "if thou wolt live or deie" (8.2148); in other words, the choice between salvific knowledge and dooming ignorance. Amans cannot comprehend why Nature decided to teach him the way to love, or in other words, to make him perceptive of the notion that something is indeed lacking in him and yet refrains from revealing to him whether he shall succeed in this quest or not. Mainly, he is insecure, standing in an unsure place of in between, without the knowledge of how to move either way. He realizes he can't go back but isn't yet sure on how to move forward. Venus then appears in answer to his plea and repeats her question from the Prologue, but this time she is half scornful; "Sche axeth me what is mi name" (8.2320). To her surprise, he replies, "John Gower" (line 2321). This moment indicates a new beginning since Amans has certainly progressed from "A caitif that lith hiere" (1.161). His identity has been re-acknowledged but the Truth still needs to be regained.

Finally, Venus hands Amans a mirror to behold his true visage. At first, the vision takes him by surprise, as it is not pleasant since that which should have been the most familiar is utterly unfamiliar, but it is his true self. And it is in this encounter with the "true self," which he now sees quite clearly that the canonical self meets and converges with "the other." It is through this mirror that is held up to his now "seeing" eyes that he gains perspective. The stories had indeed helped him "remember" by providing insight into a part of the self he had repressed. It is only through this newly gained perspective that he can finally learn to accept himself, and vicariously, the "other."

When the lesson is over, the dialogue transforms into a monologue. The monologue, a personalized narrative, serves as the literary mirror of self-awareness that symbolizes the inner quest Amans has undertaken, and it is this introspection that eventually leads to an epiphanic moment of revelation that culminates in the passing of the spirit into knowledge, a spiritual salvation and poetic closure. When Amans "stod amasid for a while, / and [then] in myself y gan to smyle" (8.2957-8), this smile holds the secrets of the universe, or as Russell Peck [9] puts it, "the smile is the final clue to his release."

In other words, such a self-revelation cannot remain on the personal level as the marginalized within the self takes center stage. Upon learning of the other in the self, Amans, or rather, every man may turn outward and perceive his surroundings through unveiled eyes, learn acceptance, as he indeed had done with himself, and embrace diversity.

\section{REFERENCES}

[1] B. Newman. What Did It Mean to Say 'I Saw'? The Clash 
between Theory and Practice in Medieval Visionary Culture, Speculum, Vol. 80, No. 1, 1-43, 2005.

[2] W. F. Hodapp. The Real and Surreal in Medieval Dream Vision: The Case of James I's Kingis Quair, The Journal of the Midwest Modern Language Association, Vol. 42, No. 1, 55-76, 2009.

[3] P. Bourdieu. Language and Symbolic Power, Harvard University Press, 1999.

[4] L. Strauss. Persecution and the Art of Writing, University of Chicago Press, 1988.

[5] D. Pearsall. Gower's Narrative Art, PMLA, Vol. 81, No. 7, 475-84, 1966.
[6] S. Nowlin. Narratives of Incest and Incestuous Narratives: Memory, Process, and the Confessio Amantis 's 'Middel Weie', Journal of Medieval and Early Modern Studies, Vol. 35, 217 44, 2005.

[7] J. Gower. Confessio Amantis, Medieval Institute Publications, Michigan, 2006.

[8] J. Simpson. Sciences and the Self in Medieval Poetry: Alan of Lille's Anticlaudianus and John Gower's Confessio Amantis, Cambridge University Press, UK, 2005.

[9] R. Peck. Introduction, In Confessio Amantis, edited by G. C. Macaulay, Medieval Academy of America, Canada, 1980. 